
МЕТОДОЛОГО-ТЕОРЕТИЧНИЙ ІНСТРУМЕНТАРІЙ
ІСТОРИКО-ПЕДАГОГІЧНИХ ДОСЛІДЖЕНЬ

\title{
METHODOLOGICAL AND THEORETICAL TOOLS FOR HISTORICAL
} AND PEDAGOGICAL RESEARCHES

\begin{abstract}
У статті висвітлено питання методологотеоретичного інструментарію історикопедагогічного дослідження. Акцентовано увагу на складниках концептуальних моделей теорії історії (наукові знання, орілософрські закони; світоглядні принципи дослідника), на специфрічних ознаках історико-педагогічних досліджень (часовий чинник, територіальна належність, відсутність експерименту, реконструкція форми знань, що набуває ознак історико-педагогічної рефрлексії; характерна розлога система посилань, критичний аналіз фокктів, комплексне використання методологічних підходів), на формі викладу історико-педагогічного дослідження (наративі), що передбачає комплекс взаємопов'язаних історичних методів, знання методології історії, навичок вивчення історичних документів, а також використання джерел, що сприяє сорормованості історико-педагогічного твердження. Наголошено на тому, що теоретичний рівень наукових досліджень залежить від методологічних знань. Зазначені структурні рівні методологічного знання (фрілософрський, загальнонауковий, конкретно науковий, технологічний), ффункції, що виконує нормативне методологічне знання (забезпечує правильність постановки проблеми наукового дослідження, визначає засоби для ії різнобічного аналізу на етапах студіювання, сприяє покращенню організації дослідження); загальнонаукові фрункції методологічного підходу (науково-світоглядна, концептуалізації, технологізаціі), основні методологічні принципи педагогічного дослідження (об'єктивності, доказовості, всебічності, сутнісного аналізу, $є$ єності історичного й логічного, наступності, системності, науковості). Висвітлено систематизацію методологічних принципів та підходів Н. Бордовської. Зосереджено увагу на чинниках підвищення якості та ефективності історико-педагогічних досліджень. Досліджено науковий дискурс понять «методологія», «методологічний підхід».

Ключові слова: історико-педагогічне дослідження, методологія, методологічні знання, методологічний підхід, методологічні принципи.
\end{abstract}

The article outlines the issues of methodological and theoretical tools to conduct historical and pedagogical research. It is focused on the components of conceptual models of history theory (scientific knowledge, philosophical laws; a researcher's worldview), on specific features of historical and pedagogical research (time factor, affiliation, no experiment, knowledge reconstruction, which bears some features of historical and pedagogical reflection. It is characterized by extensive references, critical analysis of facts, integrated application of methodological approaches). Emphasis is put on the form of presenting historical and pedagogical research (narrative), which involves a set of interrelated historical methods, knowledge of historical methodology, skills of studying historical documents as well as appropriate use of sources, which contributes to the reliability of historical and pedagogical statement. It is stressed that the theoretical level of scientific research depends on methodological knowledge. The article describes structural levels of methodological knowledge (philosophical, general scientific, specific scientific, technological), functions performed by normative methodological knowledge (ensures the correctness of the scientific research problem, determines the means for its comprehensive analysis at the stages of studying, improves research organization); general scientific functions of methodological approach (scientific worldview, conceptualization, technologization), main methodological principles of pedagogical research (objectivity, evidence, comprehensiveness, substantive analysis, unity of historical and logical, continuity, system, scientific). The systematization of methodological principles and approaches suggested by N. Bordovska is analyzed. Special attention is paid to the factors contributing to improving the quality and effectiveness of historical and pedagogical research. The scientific discourse of the concepts «methodology», «methodological approach» is researched.

Key words: historical and pedagogical research, methodology, methodological knowledge, methodological approach, methodological principles.
Постановка проблеми в загальному вигляді. Історія педагогіки, як зазначає О. Адаменко, покликана розкривати механізм руху науки, здійснювати раціональну реконструкцію історичного перетворення педагогічного знання, сприяти піднесенню теоретичного рівня сучасної педагогіки, створювати передумови для адекватної оцінки її досягнень [1, с. 1]. Підґрунтя історико-педагогічного дослідження становить методолого-теоретичний інструментарій, що сприяє інтерпретації певних явищ та подій.

Аналіз останніх досліджень і публікацій. Загальнометодологічним засадам наукових досліджень присвячені праці Н. Бордовської,
В. Ворожцова, В. Загвязінського, В. Кохановського, Т. Кристопчук, О. Москаленко, П. Образцова М. Скаткіна, С. Сисоєвої та ін. Концептуальні моделі теорії історії висвітлено в наукових розвідках В. Вороніна, Ю. Маркова, О. Розумовського, Н. Семенова, В. Шмакова. Методологія дослідження історико-педагогічного процесу розглядалася в наукових працях С. Бобришова, л. Ваховського, Е. Панасенко, 3. Равкіна, О. Сухомлинської.

Мета статті - розкрити методологічні основи історико-педагогічних досліджень.

Виклад основного матеріалу. Методологічне значення для історико-педагогічних досліджень 
мають сорормульовані науковцями вимоги до таких наукових праць. Л. Зеленська виокремлює таку низку специфічних ознак дослідження в галузі історії педагогіки, як: 1) часовий чинник (досліджувані явища та процеси стосуються певної епохи, що зумовлює інтеграцію педагогіки та історії); 2) територіальна належність (досліджувані об'єкти вивчаються в межах певного регіону); 3) відсутність експерименту (сучасний контекст наукової проблеми вступає в діалог із педагогічною проблематикою минулого, збагачує й розширює уявлення про приписи, персоналії, інституції, що сприяє вдосконаленню сучасного теоретико-методологічного пошуку; 4) джерельна та джерелознавча база, способи її опрацювання слугують базисом дослідження; 5) фрорма знань у дослідженні реконструюється, набуває характеру історико-педагогічної реслексії; 6) характерна розлога система посилань, критичний аналіз свідчень, наративна форма репрезентації досвіду [12, с. 24].

Розглядаючи концепцію історико-педагогічного дослідження як систематизований конструктивний задум наукової праці, як цілісну систему взаємопов'язаних концептів наукового пошуку, Е. Панасенко називає, крім таких його характерних ознак, як часовий чинник та територіальна належність, неможливість використання емпіричних методів наукового дослідження, комплексне використання методологічних підходів [18, с. 13].

3. Равкіним визначено шляхи підвищення якості та ефрективності історико-педагогічних досліджень: 1) подальше зростання їхнього теоретико-методологічного рівня, посилення світоглядної спрямованості й концептуального характеру; 2) забезпечення вченими-дослідниками інтеграції здобутих знань, системного та цілісного підходу до вивчення педагогічних явищ; 3) здійснення порівняльно-історичних досліджень, заснованих на типологічному аналізі досліджуваних процесів; 4) удосконалення методів обробки та аналізу історичних джерел, введення в науковий обіг нових і маловідомих документів, важливих за своїм значенням фрактів [19, с. 51].

Науковці В. Воронін, Ю. Марков, О. Розумовський, Н. Семенова, В. Шмаков, розглядаючи концептуальні моделі теорії історії, виокремили такі її складники: систему наукових знань, отриманих із фрактичного матеріалу; фрілософрські закони та принципи пояснення; світоглядні принципи історика-дослідника [9, с. 173].

Аналіз розвитку наукового знання, як зазначає В. Степін, є важливим аспектом історико-наукового дослідження, що передбачає виявлення та пояснення фрактів історії науки (емпірична історія науки), реконструкцію шляхів наукової думки, що сприяли формуванню нового знання (теоретичний рівень історико-наукових досліджень) [16, с. 137].
В історичній інтерпретації наукового тексту термін «знання» В. Візгіним тлумачиться як «продукт творчості цілого ряду особистостей, діючих певною мірою когерентно», які започаткували завдяки цьому традицію, наукову школу, науковий напрям. У межах такого підходу «за науковим знанням визнається певне право бути «історичною» реальністю <...>, володіти певною гетерогенністю, що не дозволяє здійснювати однозначний висновок «часткового» й «загального» [16, с. 324].

Г. Воробйов наголошує на тому, що логіка розвитку науки, суспільні потреби практики вимагають від дослідників цілісного та системного вивчення педагогічних процесів. На його думку, «метод дослідження реалізується в такій дослідницької технології, що забезпечує отримання необхідного й достатнього фрактичного матеріалу для побудови об'єктивно діючої закономірності описовими, фрормально-логічними або математичними засобами» [2, с. 69-70].

Теорія направлена, як уважає Е. Юдін, на отримання знань про саму дійсність, а методологія на процес отримання знань; «між теорією і методологією зберігається відношення цілі та засобу» [25, с. 50]. У структурі методологічного знання вчений виділяє такі рівні: 1) фрілософрський (загальні принципи пізнання, категоріальна упорядкованість науки; фрілософські знання виконують методологічні фрункції), 2) загальнонауковий (теоретичні концепції застосовувані до більшості дисциплін); 3) конкретно науковий (методи, принципи дослідження, застосовувані до визначеної дисципліни; методологія науки спрямована не тільки на висвітлення специфічних проблем у певній галузі знань, а й тих питань, що порушуються на більш високому методологічному рівні, наприклад, системного підходу або моделювання в педагогічному дослідженні); 4) технологічний (методика й техніка дослідження забезпечують достовірність отриманого емпіричного матеріалу, первинне опрацювання, що дає можливість увести його в масив наукового знання, яке має нормативний характер). Рівні методологічного знання утворюють складну систему, в межах якої між ними існує певна супідрядність. Водночас фрілософрський рівень $є$ змістовним підґрунтям методологічного знання, адже він визначає світоглядні підходи до процесу пізнання й перетворення дійсності [25].

М. Скаткін відзначає, що методологічні знання сприяють підвищенню теоретичного рівня дослідження, «допомагають рухатися від пізнання явищ до пізнання сутності, розкрити глибше внутрішні зв'язки між ними» [21, с. 132].

На думку В. Ворожцова та О. Москаленка, методологія - це «сплав онтологічних принципів, гносеології, логіки та теоретичного змісту науки та її методів...». Методологія конкретної науки повинна базуватися на теорії досліджуваного об'єкта 
[8, с. 14-15]. В. Кохановський уважає, що методологія - це складна, динамічна, цілісна, субординована система способів, прийомів, принципів різних рівнів, сфрери дії, спрямованості, евристичних можливостей, змістів, структур [13, с. 186].

Учені П. Атутов, 3. Малькова, М. Скаткин акцентують увагу на методологічних орієнтирах, необхідних для розроблення наукової теорії [15, с. 58]. Науковці вибирають такі методичні орієнтири й концептуальні стратегії, керуючись якими, можна описати, пояснити, спрогнозувати тенденції або напрями істотних змін педагогічного об'єкта.

Цінність методологічних орієнтирів, на думку Н. Бордовської, полягає в тому, що вони дають змогу науково обґрунтувати актуальність проблеми педагогічного дослідження та вибір методів і способів їі рішення, а також визначити межі аналізу результатів дослідження, пошуку критеріїв їх об'єктивної науково аргументованої оцінки; мають вплив на структуру, стиль наукового мислення, відбір понятійно-категоріального апарату, виклад наукового тексту, а також слугують підставою для типологізації та систематизації проявів педагогічної реальності; прогнозують конкретні зразки й фрорми наукового пізнання педагогічного об'єкта $[6$, c. 23].

П. Образцов відзначає, що методологія науки характеризує компоненти наукового дослідження (об'єкт, предмет, завдання, методи, засоби, способи), формує уявлення про послідовність дослідницької діяльності в процесі вирішення наукової задачі, набуває нормативної спрямованості, а одним з їі завдань є методологічне забезпечення дослідницької праці [17, с. 9, 13].

Важливою властивістю сучасного наукового мислення, на думку С. Сисоєвої та Т. Кристопчук, є методологічність, адже вона характеризується усвідомленим ставленням до засобів, передумов діяльності щодо фрормування та вдосконалення наукового знання [20, с. 67].

У нормативному методологічному аналізі переважають конструктивні завдання, по'вязані з розробленням «позитивних рекомендацій та правил здійснення наукової діяльності», а в дескриптивному - з ретроспективним описом уже здійснених процесів наукового пізнання [25, с. 40].

В. Загвязінський під нормативністю методологією розуміє не лише вивчення загальних принципів підходу до різних об'єктів дійсності, до різних класів наукових завдань, а й вивчення системи загальних та спеціальних методів, прийомів наукового дослідження. Теоретичний аспект педагогічної методології пов'язаний зі встановленням основних педагогічних закономірностей як вихідних передумов наукового пошуку, що включає світоглядну функцію (оцінка суспільної значимості, соціальної ролі теорії або теоретичного положення). Специфріка методологічного знання полягає в їхній спря- мованості на принципи та методи наукової та науково-практичної діяльності. Науковець відзначає, що в методологічному знанні об'єктом вивчення $€$ педагогічна наука, предметом - проблематика, структура, методи педагогічного дослідження, принципи та способи розвитку педагогічної теорії, а також упровадження її досягнень у практику, тому «важливе значення в структурі методологічного знання набувають принципи й вимоги, в яких виявлені закономірності, спільні дослідницькі підходи втілюються в категоріях діяльності (способи, методи, процедури тощо)» [11, с. 7-8, 32].

Нормативне методологічне знання виконує такі фрункції: 1) забезпечує як змістовно, так і фрормально, правильну постановку проблеми; 2) визначає засоби для вирішення поставлених завдань та проблем («інтелектуальна техніка наукової діяльності»); 3) сприяє покращенню організації дослідження [3, с. 68].

Орієнтація на аналіз сукупності педагогічних явищ та їхній розвиток як частини явищ соціальних становить сутність нового підходу до методологічних досліджень у галузі педагогіки [24, с. 39].

За С. Гончаренко, методологія педагогіки - це система знань про структуру педагогічної теорії, про принципи підходу, способи набуття знань, що відображають педагогічну дійсність, а також це система діяльності з одержання таких знань й обґрунтування програм, логіки, методів та оцінки якості дослідницької роботи. Методологія педагогіки включає такі положення: вчення про структуру й фрункції педагогічного знання; вихідні, ключові, фрундаментальні педагогічні положення (теорії концепції, гіпотези); вчення про логіку й методи педагогічного дослідження; вчення про способи використання одержаних знань для вдосконалення практики [10, с. 499].

Методологія педагогіки П. Образцовим трактується як концептуальний виклад мети, змісту, методів дослідження, що забезпечують отримання максимально об'єктивної, достовірної, систематизованої інформації про педагогічні процеси та явища. Методологія педагогіки виконує такі фрункції: 1) визначає способи отримання наукових знань, що відображають постійно змінювану педагогічну дійсність; 2) спрямовує і зумовлює основний шлях, за допомогою якого досягається конкретна науково-дослідницька мета; 3) забезпечує всебічність отримання інформації щодо досліджуваного процесу або явища; 4) сприяє уточненню, збагаченню, систематизації термінів і понять у педагогічній науці; 5) допомагає введенню нової інформації до теоретичного фронду педагогіки; 6) створює систему інорормації, що спирається на об'єктивні фракти й логіко-аналітичний інструмент наукового пізнання [10, с. 10-11].

Найсучаснішою й ефективнішою методологією історико-педагогічного дослідження Л. Ваховський 
уважає перспективну (нормативну) методологію, яка характеризується конструктивністю, створюваною за допомогою розумового моделювання, що здатна розв'язати низку завдань: забезпечення правильної постановки проблеми щодо її змісту та форми, критичне осмислення існуючих ідей, покращення організації дослідження, коректне інтегрування отриманих результатів [7, с. 8].

О. Сухомлинська акцентує увагу на фрормі викладу історико-педагогічного дослідження (наративі), що «передбачає історичні методи дослідження знань методології історії, навичок вивчення історичних документів та використання джерел, на основі яких фрормується історико-педагогічне твердження», що може мати причинний, еволюційно-генетичний, фрункціонально-генетичний, фуннціональний характер [22, с. 45].

Загальнонаукові методологічні принципи та підходи повинні бути іманентними предмету дисципліни, а також системі понять, що склалася в ній [25, с. 49]. Методологічні принципи «являють собою основні фрілософські світоглядні положення, з позицій яких ведеться наукове дослідження» [14, с. 38]. У методологічних підходах закладена фундаментальна ідея в контексті пізнання або перетворення об'єкта педагогічної реальності [6, с. 22].

Поняття «методологічний підхід» Е. Юдіним трактується як принципова методологічна орієнтація наукового дослідження, з погляду якої розглядається об'єкт дослідження (спосіб визначення об'єкта), поняття або принцип, що спрямовує загальну стратегією дослідження [25, с. 143]. Методологічний підхід уможливлює обґрунтування проєкту педагогічного дослідження; а реалізована методологія дозволяє досліднику отримати нове наукове знання [23, с. 91].

Розглядаючи сутність, зміст, фрункції методологічного підходу в наукових дослідженнях, С. Бобришов дійшов такого висновку: цей підхід не лише задає модель авторського бачення, розуміння та інтерпретації явищ, фрактів, подій в історії педагогіки, а $€$ науково обґрунтованим аксіоматичним каноном цілісного аналізу, репрезентації досліджуваного об'єкта - історико-педагогічного процесу в різних аспектах взаємозв'язку з історією суспільства, держави, культури та науки; визначає погляди на етапи розвитку об'єкта, регламентує відбір та інтерпретацію фрактологічного матеріалу, визначає аксіологічні параметри оцінки досліджуваних історико-педагогічних явищ [5, с. 42].

Науковець виокремлює функції методологічного підходу як регулятора й індикатора наукового дослідження: 1) науково-світоглядна, що сприяє сорормованості дослідних установок ученого щодо цілісного сприйняття об'єкта, комплексного співвіднесення його із соціально-історичною дійсністю; активізує рівні методологічного аналізу, відтворює науковознавчі та світоглядні погляди суб'єкта пізнання; 2) срункція концептуалізації, яка дає змогу сорормуватися концептуальній базі дослідження, досягнути узгодженості із встановленими науковими традиціями; забезпечує фрормування загальної стратегії дослідження відповідно до прийнятих парадигматичних принципів; 3) функція технологізації, що допомагає досягти коректних наукових параметрів та характеристик технологічного аспекту процесу пізнання; забезпечує вибір засобів, методів і прийомів вивчення об'єктів [4, с. 49].

Н. Бордовською систематизовано найбільш використовувані дослідниками методологічні принципи та підходи, а саме: 1) системний, цілісний, антропологічний та комплексний підходи для формування онтологічних, різнобічних уявлень про досліджуваний педагогічний об'єкт; 2) системно-структурний та функціональнодинамічний підходи, принципи безперервності й дискретності, ідеї синергетики та кібернетики, інформаційної теорії та статистичної системної імовірності - для відтворення ґенезису досліджуваного педагогічного об'єкта, визначення динаміки його розвитку та якісної зміни; 3) принцип природо- й культуровідповідності, диференціації, індивідуалізації, гуманізації, технологізації, спільної діяльності - для розкриття властивостей, опису окремих характеристик педагогічного об'єкта; 4) особистісний, діяльнісний та аксіологічний підходи - для визначення значення педагогічного процесу в загальній системі навчання та виховання; 5) процесуальний, функціональний або програмно-цільовий підходи, принципи демократизації, гуманізації, варіативності та диверсиорікації, положення теорії управління, організації, комунікації та соціальних груп - для визначення оптимальних шляхів педагогічного управління та організації педагогічного процесу [6, с. 26-27].

На переконання 3. Равкіна, від ступеня вирішення світоглядних і методологічних проблем даної галузі педагогіки залежить як науковий рівень досліджень, так і його практичне значення, а це «повинно отримати своє конкретне вираження в подоланні описовості, фрактографрічності, емпіризму <..>, в забезпеченні широких історикопедагогічних узагальнень і висновків теоретикометодологічного характеру, концептуальності й цілісності досліджень...» [19, с. 51].

Із-поміж основних методологічних принципів педагогічного дослідження науковцями С. Сисоєвою та Т. Кристопчук виокремлені такі: об'єктивності (врахування фракторів, що зумовлюють явища, умов їхнього розвитку, адекватності дослідницьких підходів, а також засобів, що дають можливість одержати справжні знання про об'єкт, передбачають виключення суб'єктивізму, однобічності й упередженості в доборі, оцінці фрактів); 
доказовості (альтернативність характеру наукового пошуку; вимога виділити й оцінити всі можливі варіанти розв'язування, виявити різні погляди на досліджуване); всебічності (комплексність підходу в дослідженні педагогічних процесів та явищ); сутнісного аналізу (співвіднесення в досліджуваних явищах загального, особливого й одиничного, проникненням в їхню внутрішню структуру, розкриття законів існування й фрункціонування, умов і фракторів їхнього розвитку, можливостей цілеспрямованої зміни); єдності історичного й логічного (поєднання вивчення історії об'єкта (генетичний аспект) і теорії (структури, фрункції, зв'язків об'єкта в його сучасному стані, а також перспектив його розвитку); наступності (урахування досвіду, традицій, наукових досягнень минулого); системності (розгляд об'єкту вивчення як системи) [20, с. 67-70]. Із принципом об'єктивності за змістом схожий принцип науковості, який визначає вимога конкретно-історичного дослідження педагогічних явищ [11, с. 34].

В. Ворожцов та О. Москаленко функціонування методологічних принципів пов'язують із такими особливостями, як забезпечення взаємозв'язку емпіричних даних, концептуального апарату, категорій та законів, ідей, гіпотез, теорій, їх структурування і «субординування» [8, с. 17].

Висновки. Отже, методолого-теоретичний інструментарій історико-педагогічного дослідження дає можливість для створення авторської моделі бачення історичних явищ та подій, їх інтерпретації, розкриває цілісність розгортання означеного питання в логіко-проблемній послідовності, акумулює інсоормацію (змістову, культурологічну, прогностичну) для визначення напрямів творчого, адаптованого до сучасних потреб використання набутого досвіду на сучасному етапі реформування системи вищої освіти України.

\section{БІБЛІОГРАФІЧНИЙ СПИСОК:}

1. Адаменко О.В. Розвиток педагогічної науки в Україні в другій половині XX століття (1950-2000рр.) : автореф. дис. ... д-ра пед. наук : 13.00.01. Луганськ, 2006. 44 C.

2. Атутов П.Р., Скаткин М.Н., Турбовский Я.С. Методологические проблемы развития педагогической науки Москва : Педагогика, 1985. 240 с.

3. Блауберг И.В., Юдин Э.Г. Становление и сущность системного подхода. Москва : Изд-во «Наука», 1973. $270 \mathrm{c}$.

4. Бобрышов С.В. Методология историко-педагогического исследования развития педагогического знания : дисс. ... д-ра пед. наук : 13.00.01. Ставрополь, 2006. 477 с.

5. Бобрышов С.В. Система методологических подходов к изучению историко-педагогического процесса. Вестник Костромского государственного университета имени Н.А. Некрасова: Основной выпуск. Кострома, 2006. № 2. С. 41-46.
6. Бордовская Н.В. Системная методология современных педагогических исследований. Педагогика. Москва, 2005. № 5. С. 21-29.

7. Ваховський Л.Ц. Методологія дослідження історико-педагогічного процесу : постановка проблеми. Шлях освіти. Київ, 2005. № 2 (36). С. 7-11.

8. Ворожцов В.П., Москаленко А.Т. Методологические установки ученого : природа и фрунцции. Новосибирск : Наука, 1986. 234 с.

9. Воронин В.Т., Розумовский О.С., Семенова Н.М. Методологические проблемы оптимизации в науке. Новосибирск : Наука, 1991. 255 с.

10. Енциклопедія освіти / АПН України ; гол. ред. В.Г. Кремень. Київ : Юрінком Інтер, 2008. 1040 с.

11. Загвязинский В.И. Методология и методика дидактического исследования. Москва : Педагогика, 1982. $160 \mathrm{c}$.

12. Зеленська Л.Д. Методи історико-педагогічного дослідження у розрізі парадигми наукового знання. «Психолого-педагогічні проблеми вищої і середньої освіти в умовах сучасних викликів : теорія і практика» : матеріали IV Міжнар. наук.-практ. конф. (м. Харків, 12 грудня 2019 р.). Харків, 2019. С. 23-26.

13. Кохановский В.П. Философрия и методология науки. Ростов н/Д : Феникс, 1999. 576 с.

14. Кыверялг А.А. Методы исследования в профессиональной педагогике. Таллин : «ВАЛГУС», 1980. $334 \mathrm{c}$.

15. Теоретико-методологические проблемы педагогики. Советская педагогика / 3.А. Малькова и др. Москва, 1982. № 3. С. 56-62.

16. Методологические проблемы историконаучных исследований (ответственный редактор И. С. Тиvосреев). Москва : Изд-во «Наука», 1982. 360 с.

17. Образцов П.И. Методы и методология психолого-педагогического исследования. СанктПетербург : Питер, 2004. 268 с.

18. Панасенко Е.А. Концепція історико-педагогічного дослідження : методологічний аналіз. Педагогічна освіта : теорія і практика. Психологія. Педагогіка. Київ, 2016. № 25. С. 11-16.

19. Равкин 3.И. Методологическая функция историко-педагогических исследований. Советская педагогика. Москва, 1984. № 12. С. 50-56.

20. Сисоєва С.О., Кристопчук Т.Є. Методологія науково-педагогічних досліджень. Рівне : Волинські обереги, 2013. 360 с.

21. Скаткин М.Н. Методология и методика педагогических исследований. В помощь начинающему исследователю. Москва : «Педагогика», 1986. 152 с.

22. Сухомлинська О. Історико-педагогічне дослідження та його «околиці». Шлях освіти. Київ, 2005. № 4 (38). C. 43-47.

23. Методологічні засади педагогічного дослідження : монографрія / Є.М. Хриков та ін. Луганськ : Вид-во ДЗ «ЛНУ імені Тараса Шевченка», 2013. 248 с.

24. Шубинский В.С. Общая теория развития педагогических явлений как предмет методологических исследований. Советская педагогика. Москва, 1982. № 3. С. 39-41.

25. Юдин Э.Г. Системный подход и принцип деятельности. Москва : Издательство «Наука», 1978. 391 c. 